research was discussed at some length and with enthusiasm. The group felt, however, that there were two basic conditions which must be met by such research: the first was that it must be stipulated that the scientific content of such projects should always be published; the second was that sponsored research should not interfere with the general research policy and the teaching duties of the university.

In the discussions of the financing of universities it was emphasised that, although universities needed to know basic data-such as staff/student ratios, number of square metres/student-for their proper management, these data had to be looked at with an expert eye if they were to be meaningful. There were no strong views about the relative merits of grants or loans for the support of students, but the group was strongly against the notion that undergraduate students, at least, should be salaried and regarded as clients. It was necessary for the university to have strong leadership if it wanted a proper system for setting priorities and wanted to retain proper autonomy.

So, all in all, was their journey really necessary? Most decidedly so, most of the delegates felt at the end. The conference had emphasised once more the strong links which unite European scholarship and the necessity of preserving and nurturing those links.

\title{
correspondence
}

\section{Adding amino acids}

SIR,-The issues that Drs Miller and Payne raise (Nature, 251, 176) may be summarised as follows:

1. No example is available of a field trial that shows measurable benefit of amino acid addition;

2. I confuse the problem of meeting physiological needs for protein with that of aesthetic demands;

3. Methionine, not lysine, is limiting in most diets, including cereal diets; 4. Talk of amino acid fortification constitutes a diversion from the main problem, poverty of large masses;

5. The only solution to the problem of malnutrition is to raise the standard of living and improve traditional agriculture.

It is true that examples of completed field trials are lacking. As I stated, (Nature, 248, 643) some are underway; others might well be started in which non-protein calories (such as cassava, sago, and plaintain, or oil) could be added to a predominantly cereal diet with added amino acids to determine how to extend the range of options for obtaining food energy balanced with protein.

I do not confuse physiological needs and aesthetic demands and stated so clearly in the section entitled "No Substitute for Aesthetics".

That methionine is limiting in cereal diets has been disputed. Bressani and Elias $^{1}$ pointed out that only when legume contributes more than $50 \%$ of the protein in a cereal-legume mixture is methionine limiting; at that level the diet is not protein-deficient.

The world protein food probleri has had an extraordinary history: it is the only major world problem that has been discovered and solved, all within a period of about 25 years, and simply by changing standards. More to the point would be statistics on the pre- valence of protein-calorie malnutrition of the kind that indicates a particular deficiency of protein-the kind that was called "kwashiorkor". Has this diminished along with the disappearance of the protein problem? And if, indeed, there is an increase of protein-calorie malnutrition of all types, then does this not emphasise even more the need to provide more food energy and point out the consequences of the protein-calorie tradeoff? That amino acid fortification does not reach all elements of a population or that it does not provide additional aesthetics in food is of secondary consequence: the critical point is that additional ways of adding protein make it possible to divert resources to more food energy, or special baby foods, or more pleasing foods.

The world food problem is an extraordinarily complex problem of massive poverty exacerbated by increasing populations and shrinking resources. What Drs Miller and Payne have to offer has been tried again and again, and has been shown inadequate. Only a total world attack can deal with this problem: affluent nations will need to distrihute more of their wealth to the poor nations at the cost of a reduction of some aspect of their own quality of life; the poor nations will need to develop policies that reduce the ratio of populations to resources. Ultimately, decisions to act involve moral considerations. But such decisions involve many other factors, among them the availability of solutions and the multiplicity of options. Is it right to deny poor countries the use of technologies that could increase their opportunities to solve problems as they cope with the basic problem of poverty?

Washington $D C$.

Aaron M. Altschul

${ }^{1}$ Bressani, R., and Elias, L. G., in New Protein Foods (edit. by Altschul, A. M.), 282 (Academic Press, 1974).

\section{Publish it not}

Sir,-I am profoundly shocked by the leading article in the issue of Nature of September 6. My dismay arises from the content of the fourth and fifth paragraphs. Firstly it seems to me to betray a surprising ignorance of the issue under discussion to draw an analogy with weather modification or shocking experimental animals. In both cases we know the consequences to be localised and if a scientist in Idaho does modify the weather, this has no consequences in India or Iceland. Climatic modification is of course a different issue. But with genome fusions, there is no reason to believe that a blunder might not have consequences which would affect very large numbers of people over a very wide area of the globe.

The second issue relates to your concept of "pushing (papers) into the underground". Certainly there are undergrounds: one is concerned with military research and the other industrial research. But it seems reasonably certain (military matters apart) that the people concerned in this particular field are ones who desire public recognition for their work and who would be discouraged very quickly if they saw that their findings would not lead to the glories of a mention in the Citation Index.

$$
\text { Yours faithfully, }
$$

\section{London.}

$$
\text { D. W. EWER }
$$

\section{Family favourites}

Sir,-On page 98 and 99 of vol. 251, there are 3 consecutive contributors named Davies.

Statistical analysis shows that the probability of this arising on the basis of chance is infinitesimally small, so it can only be nepotism!

London. 